\title{
GROUNDING DECISION IN PUBLIC INSTITUTIONS BASING ON INFORMATION PROVIDED BY FINANCIAL ADMINISTRATION BOOK- KEEPING
}

\author{
Ph.D. Student Iulian Stefan, "Valahia" University Târgoviste \\ email: iulian.stefan@mfinante.ro
}

Summary: This project will try to reveal the present situation of the organization and leading of the financial administration book-keeping in public institutions.

I have chosen this subject according with its actual state and the fact that there are public institutions which develop also economic activities in terms of the law.

To conclude I can mention that the organization and leading of the financial administration book-keeping is not absolutely necessary, I propose the elaboration of a certain law which takes account of the specific character of the activity developed in public institutions.

Economy and Finances Ministry did not emit, until present, specifications regarding the organization and leading of the financial administration book-keeping in public institutions.

Some public institutions in Romania, according to the laws and its requirements, can develop economic activities too.

For these activities, these public institutions have the legal obligation, without taking account of the realized business cipher, to be recorded as paying the V.A.T.

These act on the market like any economic agent and in order not to create an un-loyal competition between economic agents which develop similar activities; these public institutions will be forced to separate the activity as a public authority from the one as an economic agent.

Since they need information regarding the way of calculating the cost, it is necessary that the decisions of the credit orders in public institutions, which also develop economic activities, to be grounded on the elements supplied by the financial administration book-keeping.

Without having a legal basis, the result would be that public institutions can not organize and lead financial administration book-keeping, adapted to the specific developed activity.

By Order of the Minister of Public Finances no. 1826/2003 for approving Specifications regarding some measures referring to the organization and leading of the financial administration book-keeping, economic agents have the obligation to organize and lead financial administration book-keeping adapted to their specific activity.

For the simple reason that some public institutions develop economic activities with results, these would be forced to organize and lead financial administration book-keeping for their activities.

In this situation, the credit orders could suppose, on one side, that the information supplied by the financial administration book-keeping are necessary in order to ground their decisions, and on the other side that they are in the position when no specific law regarding the manner of organizing and leading the financial administration book-keeping in public institutions.

We can consider that the organization and leading of the financial administration bookkeeping in public institutions, in absence of a legal basis, runs counter the specific legislation applied by the public institutions.

Without mentioning this thing in a specific law, tacitly, Economy and Finances Minister accepted that the settlements regarding the organization and leading of the financial administration book-keeping for the economic agents to be also applied by public institutions but with no compulsory character. 
A legal environment was created so that public institutions which develop economic activities to organize and lead differently a financial administration book-keeping.

The credit orders must have information over the calculation of the cost and basing on them, they must ground their decisions.

According to the required information, they can realize products and/or services to competitive cost with other economic agents on the market who develop similar activities.

If in public institutions which develop economic activities too, the organization and leading of the financial administration book-keeping is justified by the need of owing information on the destination of the expenses, in the case of the public institutions which do not develop economic activities, the organization and leading of a financialadministration book-keeping would not be justified.

The work of the public institutions supposes certain costs.

Population should be aware of the manner the public funds are used and, for example, to be informed which are the costs required by the working of the public health system, also by the nature of the expenses but their destination too.

So far, National Health House discounts, basing on a post-calculation, the costs of the hospitalization for a patient during his affections.

In the education institutions the afferent costs for the school of a person, for all levels, are calculated and the supplied information are the basis for the estimations regarding the level of the school taxes.

In public institutions which deal with the child protection, in addition to information regarding the nature of the expenses for a child's education, separately we should also be aware of the costs like: alimentation, education etc., basing on age categories.

Regarding the information offered by the financial administration book-keeping, we observe that they would be very useful to the credit orders in the grounding of the decisions in order to reach the purposes of the public institution.

Organization and leading of the financial administration book-keeping in public institutions require certain costs for creating a specialized staff, in the financial-book-keeping department.

Actually, the financial administration book-keeper would have to inform the credit order on the situation in the public institution, indicating him measures to eliminate some disfunctionalities.

The nature of this information provided by this "informing book-keeper" would not be known by the staff of the public institution because of its confidential character.

The organizations and leading of the financial administration book-keeping in public institution should take in count the report between costs and benefits while using public funds. For example, the credit order must appreciate if the benefits brought by organizing and leading the financial book-keeping inside the staff are superior to the afferent costs for developing this activity.

Considering the size of the public institution and its purposes, the credit orders must take a decision whether the organization and leading of the financial administration book-keeping is justified economically, for them this thing representing a possibility and not a legal obligation.

Through the new account plan for public institutions and the instructions for its application, plan approved by the order of the Public Finances Minister no. 1917/2005, class 8 was created accounts not mentioned in the balance sheet, the class of the financial administration accounts.

The simple existence of this class accounts in the accounts plan for public institutions is not a legal reason for forcing them to organize and lead financial administration book-keeping adapted to the specific character of the activity.

Moreover, by the specific character of the activity developed by public institutions, these accounts do not correspond to the necessities for which they were created.

The main credit orders should judge the organization and leading of the financial administration book-keeping and the information reports supplied as this information have a confidential character and help the credit orders to ground their decisions. 
According to the specific character of the developed activity, main credit orders should create certain book-keeping accounts, not mentioned in the balance sheet, and the monograph regarding the recording in the book-keeping so that the supplied information by these accounts to correspond to the specific requirements of the activity area and to be comparable in order to obtain an unitary report regarding the expenses of the public institutions in the area.

Although public institutions develop their activity according to the approved budget which respects in structure the classification of the pointers regarding the public finances - structure approved by order of the Public Finances Minister no. 1954/2005- the collection of incomes and effecting of the expenditures can not be done using the budgetary classification as legal basis.

In other words, budgetary classification does not represent a legal reason for collecting incomes or effecting expenses to public institutions.

Presently, in public institutions we encounter certain elements regarding the organization and leading of the financial administration book-keeping. We can mention: the organization and the leading of the pledges book-keeping and the budgeting basing on programs.

The organization and leading of the pledges book-keeping in public institutions was settled basing on the order of the Public Finances Minister no. 1752/2003 regarding the employment, abolition, special orders and the payment of the expenses in public institutions.

This way were separated the attributions of the credit order from those of the book-keeper. The responsibility for the employment, abolition and special orders regarding the funds belongs to the credit order, and the payment of the expenses to the book-keeper.

In the new account plan for public institutions, in the $8^{\text {th }}$ class of the financial administration accounts, we meet the following accounts which help to the organization of the pledges bookkeeping: approved budgetary credits, budgetary pledges and legal pledges.

In order to understand how these financial administration accounts function we must mention that the difference between the balance of the account "approved budgetary credits" and the balance of the account "budgetary pledges" represent, at some moment in time, the budgetary credits which can still be used for expenses.

Also, the difference between the balance of the account "budgetary pledges" and the expenses made in order to complete the obligations of the public institution represent pledges which did not reach the final term.

A correct evidence of the pledges allows the credit order to employ the institution in effecting expenses limited to the approved credits and still available.

The pledges book-keeping offers only information referring to the financial administration of the credits.

The rule of the annual budget and the multi-annual actions realized by public institution imposed the necessity of offering to the incomes and expenses budget of a public institution the character of a future plan.

It was imposed the difference between budgetary authorization in budgetary credit and pledge credit. In fact, the budgetary credit represents an authorization for expenses and the pledge credit represents an authorization for pledge which can generate expenses in the future budgetary exercises.

The budget is no longer a settlement action, strictly limited to a budgetary exercise; it implies annual actions and multi-annual actions structured in programs, sub-programs, purposes etc.

The specialization of the budgetary authorization in budgetary and pledges credits is related to the budgetary financial administration basing on programs, which means an orientation towards results.

The philosophy of structuring a budget was modified so that the budget is no longer grounded on the needs of the main credit orders - who required resources for developing the activity - nowadays this is elaborated basing on the programs who will be financed, which means that the structure of the budget is orientated on results. 
The projects for the budgets are elaborated by the Government, by the order of the Economy and Finances Minister, basing on the programs presented by the main credit orders in order to finance some actions ore a group of actions, which are associated with precise purposes and result and efficiency indicators; programs are sustained by the annual estimation of the performances of each program which must mention: actions, associated cost, purposes, obtained results and estimated results for the following years, measured by physics indicators for efficiency and results.

The programs are approved as annex to the budgets of the main credit orders.

The credit orders are responsible, according the law, for organizing the evidence of the programs, including their afferent indicators.

To conclude, the new account plan for public institutions based on the supplementation of ready fluxes book-keeping with the obligation book-keeping. If we trust the fact that in public institutions the pledge book-keeping also respects the accrual principle - according which the incomes and expenses are registered in the book-keeping by the moment of the operations and not when the incomes were charged or the expenses were paid - we can observe that the organization and leading of the pledge book-keeping offers information on the budgetary pledges which did not reach the final date and on the available account which can be employed by a public institution according to the income and expense budget approved.

Because the public institutions administrate public funds and their activity does not focus on obtaining profit, it is not considered necessary that the costs of their functioning after destination to be known.

As public institutions administrate public funds, the manner of utilization for these funds must be transparent, I recommend the elaboration of a specific law by which they organize and lead the financial administration book-keeping, adapted to the specific character of the activity.

Regarding the specific character of the developed activity in public institutions, it is necessary to elaborate a specific law in order to settle the organization and leading of the financial administration book-keeping in public institutions for the following reasons:

- public institutions must offer ransparently information related to the manner that the public funds are spent according to the nature and destination;

- the possibility of introducing some new financial administration accounts who correspond to the specific requirements in certain activity areas;

- it must be evidenced differently the economic activity developed by some public institutions by the activity developed as a public authority;

- by elaborating a specific law it is eliminated the possibility of organizing and leading the financial administration book-keeping in public institutions, this becoming a legal obligation.

There are some arguments in favor of elaborating a certain law which can settle the organization and leading of the financial administration book-keeping in public institutions.

\section{Bibliography:}

1. Briciu Sorin, "The informational system regarding the financial administration book-keeping and the calculation of the costs in industry", P.h. Argus, Bucharest, 2000;

2. Briciu Sorin, Burja Vasile "Financial administration book-keeping. The calculation and analysis of the costs.", P.h. Ulise, Alba Iulia, 2004;

3. Cucui Ion, Horga Vasile, M. Radu, "Financial administration book-keeping", P.h: Niculescu, Bucharest, 2003

4. Cucui Ion, Horga Vasile, M. Radu, "Financial administration control", P.h: Niculescu, Bucharest, 2003

5. Dumitru Corina Graziella, Ioanas Corina "Financial administration book-keeping and the evaluation of the performances" Universitary Publishing House, Bucharest, 2005

6. Niculescu Maria, "Economic diagnosis" - vol. I., P.h: Economica, Bucharest, 2003

7. Niculescu Maria, "Economic diagnosis" - vol. II, P.h: Economica, Bucharest, 2005 
8. Niculescu Maria, "Increasing strategies", P.h: Economica, Bucharest, 1999

9. Preventive financial control manual: Project elaborated by the Public Finances Ministry, General Direction for Preventive Financial Control

10. Todea Nicolae., "Book-keeping, theoretical aspects and practical applications", P.h: Aeternitas, Alba Iulia, 2002 